\title{
PROFIL KEMAMPUAN BERPIKIR KREATIF MAHASISWA DALAM MENGAJUKAN MASALAH PERSAMAAN DIFERENSIAL
}

\author{
Wasilatul Murtafiah \\ Program Studi Pendidikan Matematika, FKIP, Universitas PGRI Madiun \\ e-mail: wasila.mathedu@unipma.ac.id
}

\begin{abstract}
Problem Posing approach is necessary for teacher training students. Problem Posing can train students to create questions/problems and their solutions. Make problem then solve it is part of student's creative thinking ability. Differential equations problem is one of the materials that learned in mathematics education courses. Every teacher training student of mathematics has diverse skills. This diversity certainly brings various creative thinking skills as well. The purpose of this study is to determine the ability of student's creative thinking in mathematical education courses, differential equation problem posing. This study uses a qualitative approach with descriptive methods. Sources of data in this study are the students of mathematics education consist of one student of each with high, medium, and low begining math ability. The data collection was conducted by using observation, testing, and interviews. Technique authenticity of data using a triangulation method. Data analysis technique done in stages, data reduction, data presentation, drawing conclusions, and verification. The result of this study were (1) Students with high initial capability not have fluency and flexibility of thought, but it shows the novelty think that qualifies as a Creative Thinking Ability Level (CTAL) 2 is creative enough, (2) Students with prior knowledge currently have the fluency of thought, but do not have the flexibility and novelty think that qualifies as a Level capabilities creative thinking (CTAL) 1 is less creative, (3) Students with prior knowledge low yet has grace, eloquence, and the novelty of thought that goes into the criteria of creative thinking ability Level (CTAL) 0 is not creative.
\end{abstract}

Keyword: Creative Thinking Ability; Problem Posing; Differential Equation

\begin{abstract}
Abstrak: Pendekatan pengajuan masalah (problem posing) penting bagi mahasiswa calon guru. Pengajuan masalah dapat melatih mahasiswa dalammembuat soal/masalah beserta penyelesaiannya. Membuat masalah yang kemudian menyelesaikannya merupakan bagian dari kemampuan mahasiswa dalam berpikir kreatif.Masalah persamaan diferensial merupakan salah satu materi yang diajarakan pada program studi pendidikan matematika. Setiap mahasiswa calon guru matematika memiliki kemampuan yang beragam. Keberagaman ini tentu memunculkan kemampuan berpikir kreatif yang beragam pula. Tujuan penelitian ini adalah untuk mengetahui kemampuan berpikir kreatif mahasiswa program studi pendidikan matematika dalam mengajukaan masalah persamaa diferensial. Pendekatan penelitian yang digunakan kualitatif dengan metode deskriptif. Sumber data pada penelitian ini adalah mahasiswa program studi pendidikan matematika yang terdiri dari masing-masing 1 mahasiswa dengan kemampuan awal tinggi, sedang, dan rendah. Pengumpulan data dilakukan dengan metode observasi, tes, dan wawancara. Teknik keabsahan data menggunakan triangulasi metode. Teknik analisis data melalui reduksi data, dilanjutkan penyajian data, penarikan kesimpulan, dan verifikasi.Hasil penelitian ini adalah (1) Mahasiswa dengan kemampuan awal tinggi belum memiliki kefasihan dan keluwesan berpikir, tetapi menunjukkan kebaruan berpikir sehingga masuk dalam kriteria Tingkat Kemampuan Berpikir Kreatif (TKBK) 2 yaitu cukup kreatif, (2) Mahasiswa dengan kemampuan awal sedang memiliki kefasihan berpikir, tetapi belum memiliki keluwesan dan kebaruan berpikir sehingga masuk dalam kriteria Tingkat Kemampuan Berpikir Kreatif (TKBK) 1 yaitu kurang kreatif, (3) Mahasiswa dengan kemampuan awal rendah belum memiliki keluwesan, kefasihan, dan kebaruan berpikir sehingga masuk ke dalam kriteria Tingkat Kemampuan Berpikir Kreatif (TKBK) 0 yaitu tidak kreatif.
\end{abstract}

Kata Kunci:Berpikir Kreatif;Pengajuan Masalah; Persamaan Diferensial 


\section{PENDAHULUAN}

Perguruan tinggi yang mengasilkan calon guru merupakan Lembaga Pendidikan Tenaga Kependidikan (LPTK). Seorang calon guru dituntut untuk meningkatkan kompetensinya agar menjadi guru yang profesional. Seorang guru merupakan pendidik yang profesional apabila memiliki empat kompetensi yaitu profesional, pedagogik, sosial dan kepribadian. Hal ini tentu menuntut LPTK untuk mencetak calon guru yang memiliki keempat kompetensi tersebut.

Dalam kaitannya dengan kompetensi profesional, kompetensi ini adalah kompetensi yang sangat berhubungan erat dengan bidang studi atau kepakaran masing-masing guru. Penguasaan tentang keilmuan serta karakterikstik dari bidang studi merupakan bentuk dari kompetensi ini. Tentu saja, penguasaan keilmuan antara guru bahasa dengan guru bidang eksak sangat berbeda. Begitu juga dengan pendekatan-pendekatan pembelajaran yang digunakan juga harus sesuai dengan karakteristik materi bidang studi.

Demikian halnya dengan guru matematika. Seorang guru matematika dituntut untuk mampu menguasai materi serta pendekatan pembelajaran yang sesuai dengan karakteristik materi yang diajarakan. Ini tentu disesuaikan dengan tujuan pembelajaran matematika dalam Kurikulum Tingkat Satuan Pendidikan (KTSP) yang juga sejalan dengan penyempurnaan pada Kurikulum 2013, yaitu agar siswa, (1) memahami konsep matematika, menjelaskan keterkaitan antarkonsep dan mengaplikasikan konsep atau algoritma secara luwes, akurat, efisien, dan tepat dalam pemecahan masalah; (2) menggunakan penalaran pada pola dan sifat, melakukan manipulasi matematika dalam membuat generalisasi, menyusun bukti, atau menjelaskan gagasan, dan pernyataan matematika; (3) memecahkan masalah; mengkomunikasikan gagasan dengan simbol, tabel, diagram, atau media lain untuk memperjelas keadaan atau masalah, dan (5) memiliki sikap menghargai kegunaan matematika dalam kehidupan, rasa ingin tahu, perhatian, dan minat dalam mempelajari matematika, serta sikap ulet, dan percaya diri dalam pemecahan masalah (Depdiknas, 2006).

Tujuan tersebut akan tercapai apabila diselaraskan dengan kompetensi calon guru matematika yang dibekalkan di perguruan tinggi. Kita tahu bahwa matematika merupakan materi pelajaran yang berkaitan erat dengan kehidupan sehari-hari. Melalui pembelajaran matematika seorang guru matematika diharapkan mampu menumbuhkan sikap kritis dan kreatif siswa dalam berpikir, baik dalam mengajukan masalah (problem posing) maupun dalam memecahkan masalah (problem solving). Terdapat bermacam-macam model serta pendekatan pembelajaran berkembang saat ini yang dapat membantu siswa dalam memunculkan kemampuan berpikir kritis serta kreatif salah satunya adalah pendekatan problem posing.

Kemampuan berpikir kreatif pada setiap orang bersifat tidak tetap dan dapat berkembang. Perbedaan kemampuan, wawasan serta lingkungan seseorang merupakan beberapa faktor yang berpengaruh terhadap kemampuan berpikir seseorang. Demikian halnya dengan kemampuan berpikir kreatif siswa maupun mahasiswa calon guru dalam pembelajaran matematika.

Dalam pembelajaran matematika, kemampuan berpikir kreatif mahasiswa 
dapat dilihat dari kemampuannyapada saat mengajukan masalah serta memecahkan masalah. Pada saat mengajukan masalah, mahasiswa diminta untuk membuat masalah yang berkaitan dengan materi yang disampaikan, kemudian masalah yang dibuat tersebut diselesaikan. Adanya perbedaan dalam mengajukan masalah dapat memung-kinkan beragamnya masalah yang diajukan. Masalah yang diajukan bisa jadi masalah dengan beragam penyelesaian yang dapat ditemukan, masalah dengan satu penyelesaian maupun masalah yang tidak dapat diselesaikan. Sehingga melaluipengajuan masalah, mahasiswa dilatih untuk semakin kreatif dalam membuat masalah dan juga dalam memecahkan masalah. Ini penting bagi mahasiswa calon guru matematika, mengingat menjadi seorang guru matematika harus mampu membuat soal/masalah serta mampu menjelaskan pemecahannya kepada siswa.

Salah satu masalah dalam pembelajaran calon guru matematika adalah masalah persamaan diferensial. Masalah persamaan diferensial pada penelitian ini merupakan masalah dalam bentuk soal-soal penyelesaian persamaan diferensial. Melalui pembuatan soal tersebut, kemampuan berpikir kreatif mahasiswa akan lebih terlihat, baik dari segi pemahaman konsep mahasiswa maupun dari keruntutan serta kejelasan dalam menentukan penyelesaian persamaan diferensial. Kemampuan dalam mengajukan soal persamaan diferensial ini juga menunjukkan pemahaman konsep mahasiswa terhadap materi-materi prasyarat pada kalkulus diferensial dan integral yang juga merupakan materi yang diajarkan di sekolah.
Mahasiswa calon guru di program studi pendidikan matematika Universitas PGRI Madiun yang mengampu matakuliah persamaan diferensial pada tahun akademik 2016/2017 sebanyak 3 kelas dengan jumlah 90 mahasiswa. Banyaknya jumlah mahasiswa disetiap jenjang kelas dengan keberagaman latar belakangini memungkinkan beragamnya tingkat berpikir kreatif yang dimiliki oleh mahasiswa.

Berdasarkan uraian di atas maka peneliti termotivasi untuk melihat gambaran mengenai kemampuan berpikir kreatif mahasiswa program studi pendidikan matematikamelaluipengajauan masalah (problem posing) persamaan diferensial. Dengan demikian, tujuan dari penelitian ini adalahuntuk mengetahui kemampuan berpikir kreatif mahasiswa program studi pendidikan matematikamelaluipengajuan masalah (problem posing) persamaan diferensial.

\section{METODE PENELITIAN}

Penelitian dilakukan terhadap mahasiswa program studi pendidikan matematika tahun akademik 2016/2017.Pendekatan yang digunakan dalam penelitian ini adalah pendekatan kualitatif dengan metode deskriptif. Metode deskriptif menurut Sugiyono (2014: 21) merupakan metode yang digunakan untuk menggambarkan atau menganalisis suatu hasil penelitian tetapi tidak digunakan untuk membuat kesimpulan yang lebih luas. Yang digambarkan/dianalisis dalam penelitian ini adalah kemampuan berpikir kreatif mahasiswa dalammengajukan masalah(problem posing) persamaan diferensial. 
Sumber datadalam penelitian ini adalah mahasiswa program studi pendidikan matematika, FKIP, Universitas PGRI Madiun Tahun Akademik 2016/2017. Teknik pengambilan subjek menggunakan purposive sampling yaitu teknik pengambilan sampel sumber data dengan pertimbangan tertentu (Sugiyono 2014: 218-219). Subjek diambil berdasarkan pengelompokkan mahasiswa ke dalam tingkat kemampuan awal tinggi, sedang, dan rendah. Kemampuan awal mahasiswa dilihat dari nilai matakuliah kalkulus diferensial dan kalkulus integral yang merupakan kemampuan prasyarat dalam mempelajarai persamaan diferensial. Pengumpulan data pada penelitian ini digunakan teknik, antara lain: (1) Dokumentasi, yaitu bahan yang menyimpan sejumlah besar fakta dan data (Arifin 2012: 171). Dokumentasi yang digunakan dalam penelitian ini berupa data nilai subjek pada matakuliah prasyarat (Kalkulus Diferensial dan Kalkulus Integral), hasil tes, foto kegiatan, dan rekaman saat pelaksanaan wawancara, (2) Observasi, yaitu suatu proses melihat, mengamati, dan mencermati serta merekam perilaku secara sistematis untuk suatu tujuan tertentu (Cartwright dalam Suharsaputra, 2012: 209). Pada penelitian ini, observasi dilakukan tidak terstruktur sebelum dan pada saatpenelitian berlangsung. Observasi sebelum penelitian dilakukan untuk mengetahui siswa pada saat pembelajaran persamaan diferensial. Adapun observasi saat penelitian bertujuan mengetahui kemampuan berpikir kreatif mahasiswa dalam mengajukan masalah persamaan diferensial, (3) Tes, yaitu serentetan pertanyaan yang digunakan untuk mengukur keterampilan, pengetahuan intelegensi, kemampuan atau bakat yang dimiliki oleh individu atau kelompok (Arikunto, 2010: 193). Tes yang diberikan pada merupakan tes pengajuan masalah persamaan diferensial. Setiap subjek yang telah ditentukan diminta untuk mengajukan masalah dalam bentuk soal persamaan diferensial yang kemudian diselesaikan. Teknik berikutnya yang digunakan adalah (4) Wawancara, yaitu pertemuan antara dua orang dalam bertukar informasi serta ide melalui tanya jawab, sehingga dapat dikonstruksikan makna pada suatu topik tertentu (Esterberg dalam Sugiyono, 2014: 231). Wawancara di sini menggunakan wawancara semiterstruktur (semistructure interview) yang dilakukan dengan subjek terpilih berdasarkan nilai kemampuan prasyarat. Wawancara dilakukan sesuai pedoman wawancara yang telah disusun untuk mengungkap kemampuan berpikir kreatif mahasiswa.

Sedangkan indikator kemampuan berpikir kreatif mahasiswa dalam mengajukan masalah yang digunakan dalam peneltian ini adalah memodifikasi dariMunandar (dalam Hendriana dan Soemarmo, 2014: 43) sebagai berikut.

Tabel 1. Indikator Berpikir Kreatif dalam Pengajuan Masalah Matematika

\begin{tabular}{|c|c|}
\hline $\begin{array}{l}\text { Komponen } \\
\text { Kreativitas }\end{array}$ & Pengajuan Masalah \\
\hline $\begin{array}{l}\text { Kefasihan } \\
\text { (Fluency) }\end{array}$ & $\begin{array}{l}\text { Mahaiswa membuat banyak } \\
\text { masalah yang dapat dipecahkan. } \\
\text { Mahasiswa berbagi masalah yang } \\
\text { diajukan. }\end{array}$ \\
\hline $\begin{array}{l}\text { Fleksibilitas } \\
\text { (Flexibility) }\end{array}$ & $\begin{array}{l}\text { Mahasiswa mengajukan masalah } \\
\text { yang dapat dipecahkan dengan cara } \\
\text { yang berbeda-beda. } \\
\text { Siswa menggunakan pendekatan } \\
\text { "what-if-not?" untuk mengajukan } \\
\text { masalah. }\end{array}$ \\
\hline $\begin{array}{l}\text { Kebaruan } \\
\text { (Novelty) }\end{array}$ & $\begin{array}{l}\text { Mahasiswa memeriksa beberapa } \\
\text { masalah yang diajukan kemudian } \\
\text { mengajukan suatu masalah yang } \\
\text { berbeda. }\end{array}$ \\
\hline
\end{tabular}


Berdasarkan indikator berpikir kreatif dalam pengajuan masalah persamaan diferensial dapat dideskripsikan sebagai berikut.

1. Mahasiswa dikategorikan memiliki kefasihan (fluency) dalam berpikir apabiladapat mengajukan masalah persamaan diferensialpaling sedikit dua serta mampu menyelesaikannya dengan benar.

2. Mahasiswa dikategorikan memiliki keluwesan (fleksibility) dalam berpikir apabila mampu mengajukan masalah persamaan diferensialdengancara penyelesaian berbeda lebih dari satu cara.

3. Mahasiswa dikategorikan memiliki kebaruan (novelty) berpikir apabila mahasiswa mengajukan masalah persamaan diferensial paling sedikit dua yang berbeda/tidak biasa dibuat oleh mahasiswa pada tingkat pengetahuannya. Masalah persamaan diferensial yang diajukan memiliki tingkat penyelesaian yang sulit.

Teknik analisis data dilakukan melalui reduksi data, yang dilanjutkan penyajian data, serta penarikan kesimpulan dan verifikasi(Miles dan Huberman dalam Moleong, 2012).Kemudian, data yang diperolehdiuji keabsahannya dengan menggunakan triangulasi metode. Triangulasi metode dilakukan dengan membandingkan data hasil tes dan wawancara terhadap subjek.Selanjutnya, untuk tingkatan kemampuan berpikir mahasiswa digunakan penjen-jangan kemampuan berpikir kreatif dalam pengajuan masalah matematika menurut Siswono (2005).

\section{HASIL DAN PEMBAHASAN}

Berdasarkan hasil analisis data tes dan wawancara terhadap subjek terkait pengajuan masalah persamaan diferensial,makadiperoleh hasil penelitian sebagai berikut.

\section{Subjek 1 (Kemampuan Awal Tinggi)}

Berikut ini merupakan pengajuan masalah persamaan diferensial oleh subjek 1 .

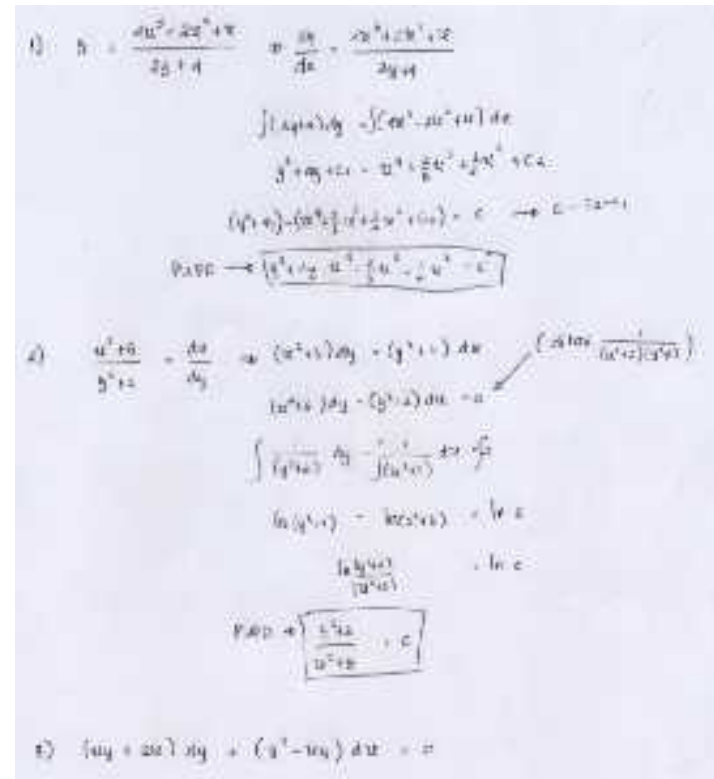

Gambar 1. Pengajuan Masalah Subjek 1

Berdasarkan analisis data hasil tes tulis dan wawancara yang telah divalidasi, diketahui bahwa subjek 1 dalam mengajukan masalah persamaan diferensial menunjukkan kefasihan berpikir karena mampu mengajukan tiga masalah dengan lancar dan dapat diselesaikan, meskipun penyelesaiannya hanya benar untuk satu masalah (masalah pertama). Penyelesaian masalah kedua salah pada konsep pengintegralan serta masalah ketiga belum diselesaikan.Subjek 1 tidak menunjukkan keluwesan berpikir yaitu hanya dapat menyelesaikan satu masalah yang diajukan dengan satu cara dan kurang benar dalam menyelesaikan masalah yang kedua. Subjek 1 
menunjukkan kebaruan berpikir karena mampu mengajukan masalah persamaan diferensial yang berbeda/tidak biasa. Masalah yang dibuat merupakan masalah baru yang belum pernah diajarkan pada saat perkuliahan.

\section{Subjek 2 (Kemampuan Awal Sedang)}

Hasil tes pengajuan masalah persamaan diferensial subjek 2 dapat dilihat sebagai berikut.

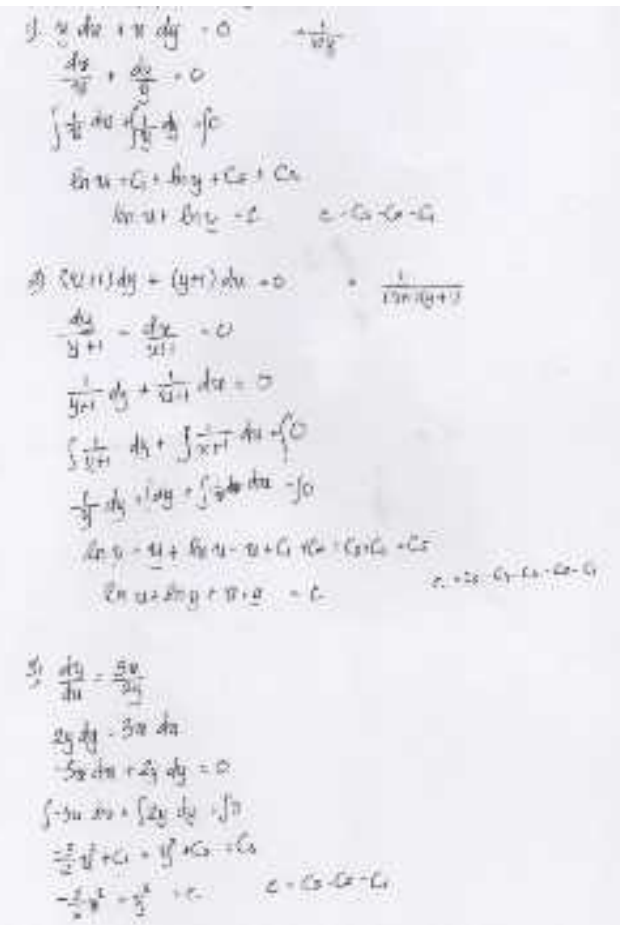

Gambar 2. Pengajuan Masalah Subjek 2

Setelah validasi hasil analisis data tes dan wawancara, maka diketahui bahwa subjek 2 dalam mengajukan masalah persamaan diferensial menunjukkan kefasihan berpikir yaitu mampu mengajukan tiga masalah persamaan diferensial dengan lancar serta dapat menyelesaikannya dengan benar. Subjek 2 menunjukkan keluwesan berpikir dengan menyelesaikan tiga masalah yang diajukan dengan urutan langkah yang berbeda. Subjek 2 belum memiliki kebaruan berpikir karena tidak mengajukan masalah persamaan diferensial yang berbeda/tidak biasa. Semua masalah yang diajukan oleh subjek 2 merupakan masalah sejenis yaitu persamaan diferensial orde satu dengan variabel dapat dipisah dan sudah pernah disampaikan sebelumnya pada saat perkuliahan.

\section{Subjek 3 (Kemampuan Awal Rendah)}

Berikut merupakan hasil tes tulis pengajuan persamaan diferensial oleh subjek 3.

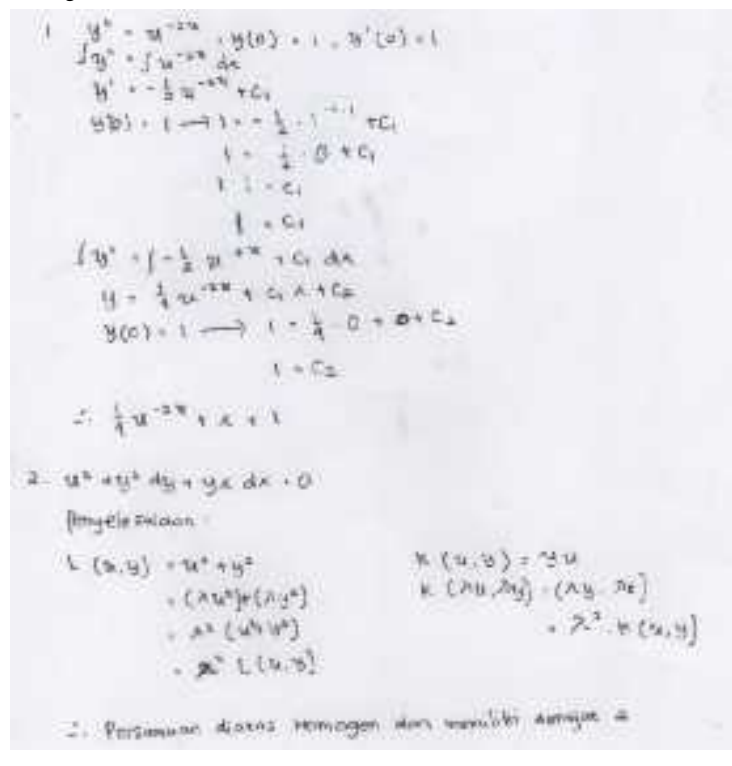

Gambar 3. Pengajuan Masalah Subjek 3

Subjek 3 dalam mengajukan masalah persamaan diferensial belum menunjukkan keluwesan berpikir karena subjek hanya mampu membuat dua persamaan diferensial tetapi belum mampu menyelesaikan satu masalah yang diajukan. Subjek 3 belum menunjukkan kefasihan berpikir karena hanya mampu mengajukan dua masalah persamaan diferensial tetapi belum mampu menyelesaikannya. Kebaruan berpikir subjek 3 belum nampak karena belum mampu mengajukan masalah matematika yang berbeda/tidak biasa. Kedua masalah yang dibuat merupakan masalah yang pernah dicontohkan pada saat perkuliahan. 
Dari hasil ketiga subjek tersebut maka dapat dikategorikan ke dalam tingkat kemampuan berpikir kreatif sebagai berikut.

Tabel 2. Kemampuan Berpikir Kreatif

Mahasiswa dalam Pengajuan Masalah Persamaan Diferensial

\begin{tabular}{|c|c|c|c|c|}
\hline \multirow{2}{*}{ Subjek } & \multicolumn{3}{|c|}{$\begin{array}{c}\text { Indikator Kemampuan Berpikir } \\
\text { Kreatif }\end{array}$} & \multirow{2}{*}{ TKBK } \\
\hline & $\begin{array}{c}\text { Kefasihan } \\
\text { (fluency) }\end{array}$ & $\begin{array}{l}\text { Keluwesan } \\
\text { (flexibility) }\end{array}$ & $\begin{array}{l}\text { Kebaruan } \\
\text { (novelty) }\end{array}$ & \\
\hline 1 & $\begin{array}{l}\text { Belum } \\
\text { memenuhi } \\
\text { indikator } \\
\text { kefasihan } \\
\text { berpikir } \\
\text { karena } \\
\text { mampu } \\
\text { mengajukan } \\
\text { tiga } \\
\text { masalah } \\
\text { persamaan } \\
\text { diferensial } \\
\text { dengan } \\
\text { lancar } \\
\text { namun } \\
\text { belum } \\
\text { mampu } \\
\text { menyelesai } \\
\text { kannya } \\
\text { dengan } \\
\text { benar. }\end{array}$ & $\begin{array}{l}\text { Belum } \\
\text { memenuhi } \\
\text { indikator } \\
\text { keluwesan } \\
\text { berpikir } \\
\text { karena mampu } \\
\text { mengajukan } \\
\text { tiga masalah } \\
\text { matematika } \\
\text { yang dapat } \\
\text { diselesaikan } \\
\text { tetapi belum } \\
\text { mampu } \\
\text { menyelesaikan } \\
\text { nya dengan } \\
\text { langkah } \\
\text { berbeda. }\end{array}$ & $\begin{array}{l}\text { Memenuhi } \\
\text { indikator } \\
\text { kebaruan } \\
\text { berpikir } \\
\text { karena } \\
\text { mampu } \\
\text { mengajukan } \\
\text { masalah } \\
\text { persamaan } \\
\text { diferensial } \\
\text { berbeda/tida } \\
\text { k biasa dari } \\
\text { masalah- } \\
\text { masalah } \\
\text { yang sudah } \\
\text { ada } \\
\text { sebelumnya. }\end{array}$ & $\begin{array}{l}\text { TKBK } 2 \\
\text { (Cukup } \\
\text { Kreatif) }\end{array}$ \\
\hline 2 & $\begin{array}{l}\text { Memenuhi } \\
\text { indikator } \\
\text { kefasihan } \\
\text { berpikir } \\
\text { karena } \\
\text { mampu } \\
\text { mengajukan } \\
\text { tiga } \\
\text { masalah } \\
\text { persamaan } \\
\text { diferensial } \\
\text { dengan } \\
\text { lancar dan } \\
\text { mampu } \\
\text { menyelesai } \\
\text { kannya } \\
\text { dengan } \\
\text { benar. }\end{array}$ & $\begin{array}{l}\text { Belum } \\
\text { memenuhi } \\
\text { indikator } \\
\text { keluwesan } \\
\text { berpikir } \\
\text { karena mampu } \\
\text { mengajukan } \\
\text { tiga masalah } \\
\text { matematika } \\
\text { yang dapat } \\
\text { diselesaikan } \\
\text { tetapi hanya } \\
\text { mampu } \\
\text { menyelesaikan } \\
\text { ketiga masalah } \\
\text { yang diajukan } \\
\text { dengan satu } \\
\text { cara. }\end{array}$ & $\begin{array}{l}\text { Belum } \\
\text { memenuhi } \\
\text { indikator } \\
\text { kebaruan } \\
\text { berpikir } \\
\text { karena } \\
\text { belum } \\
\text { mampu } \\
\text { mengajukan } \\
\text { masalah } \\
\text { matematika } \\
\text { yang } \\
\text { berbeda/tida } \\
\text { k biasa dari } \\
\text { masalah- } \\
\text { masalah } \\
\text { matematika } \\
\text { yang sudah } \\
\text { ada } \\
\text { sebelumnya. }\end{array}$ & $\begin{array}{l}\text { TKBK 1 } \\
\text { (Kurang } \\
\text { Kreatif) }\end{array}$ \\
\hline 3 & $\begin{array}{l}\text { Belum } \\
\text { memenuhi } \\
\text { indikator }\end{array}$ & $\begin{array}{l}\text { Belum } \\
\text { memenuhi } \\
\text { indikator }\end{array}$ & $\begin{array}{l}\text { Belum } \\
\text { memenuhi } \\
\text { indikator }\end{array}$ & $\begin{array}{c}\text { TKBK 0 } \\
\text { (Tidak } \\
\text { Kreatif) }\end{array}$ \\
\hline
\end{tabular}

\begin{tabular}{lll}
\hline kefasihan & keluwesan & kebaruan \\
berpikir & berpikir & berpikir \\
karena & karena mampu & karena \\
hanya & mengajukan & belum \\
mampu & dua masalah & mampu \\
mengajukan & persamaan & mengajukan \\
dua & diferensial & masalah \\
masalah & yang dapat & persamaan \\
persamaan & diselesaikan & diferensial \\
diferensialte & tetapi belum & yang \\
tapi belum & mampu & berbeda/ \\
mampu & menyelesaikan & tidak biasa \\
menyelesai & masalah yang & dari masalah \\
kannya & diajukan & yang sudah \\
dengan & dengan dua & ada \\
benar. & cara yang & sebelumnya \\
& berbeda. & \\
\hline
\end{tabular}

Hasil penelitian ini menunjukkan perbedaan kemampuan berpikir kreatif pada mahasiswa dengan kemampuan awal yang berbeda. Hasil tersebut didukung oleh Siswono (2005: 11) yang menyatakan bahwa, siswa yang memiliki kemampuan berbeda akan mempunyai kemampuan kreatif yang berbeda-beda pula. Selain itu, hasil ini juga menunjukkan bahwa masih rendahnya kemampuan berpikir kreatif mahasiswa calon guru matematika. Permasalahan ini tentu harus segera dicari penyelesaiannya mengingat pentingnya peran guru dalam melatihkan kemampuan berpikir kreatif kepada siswanya kelak. Agar guru dapat melatihkan kemampuan berpikir kreatif pada siswa maka guru matematika harus memiliki dan terus mengembangkan kemampuan berpikir kreatifnya terlebih dahulu sebelum mengajar siswanya. Langkah tersebut dapat dilakukan guru melalui peningkatan kualitas pembelajaran matematika di sekolah. Sejalan dengan ACARA, 2013b; Bray, 2011; Kwan \& Wong, 2014; NSW DET, 2003; Siswono, 2010 dalam Sanders (2016:25) yang menyatakan bahwa quality teaching pedagogy aligned with current literature highlight theimportance of establishing a mathematically thinking culture for students to generate andevaluate knowledge, and seek ideas and solutions. Kualitas pembelajaran 
sebaiknya selaras dengan literatur saat ini mengingat pentingnya membangun budaya berpikir matematis bagi siswa untuk menghasilkan dan mengevaluasi pengetahuan, dan mencari ide-ide dan solusi.Penentuan ide/gagasan serta mencari solusi terhadap permasalahan yang terjadi saat ini tidak lepas dari kemampuan berpikir kreatif.

\section{KESIMPULAN DAN SARAN}

Berdasarkan hasil pembahasan penelitian, maka dapat diambil kesimpulan sebagai berikut.

1. Mahasiswa dengan kemampuan awal tinggibelum memiliki kefasihan dan keluwesan berpikir, tetapi menunjukkan kebaruan berpikir sehingga masuk dalam kriteria Tingkat Kemampuan Berpikir Kreatif (TKBK) 2 yaitu cukup kreatif.

2. Mahasiswa dengan kemampuan awal sedangmemiliki kefasihan berpikir, tetapibelum memiliki keluwesan dan kebaruan berpikir sehingga masuk dalam kriteria Tingkat Kemampuan Berpikir Kreatif (TKBK) 1 yaitu kurang kreatif.

3. Mahasiswa dengan kemampuan awal rendahbelum memiliki keluwesan, kefasihan, dan kebaruanberpikir sehingga masuk ke dalam kriteria Tingkat Kemampuan Berpikir Kreatif (TKBK) 0 yaitu tidak kreatif.

Dari hasil penelitian ini, peneliti memberikan saran sebagai berikut.

1. Bagi Mahasiswa

a. Mahasiswa dengan kemampuan awal tinggi diharapkan dapat meningkatkan kemampuan berpikir kratifnya dengan sering berlatih pengajuan masalah persamaan diferensial maupun masalah matematika lain agar kemampuan berpikir kreatifnya semakin berkembang.

b. Mahasiswa dengan kemampuan awal sedang diharapkan dapat mengajukan masalah persamaan diferensial maupun masalah matematika lainnya dengan lebih bervariasi (tidak monoton) agar kemampuan berpikir kreatifnya semakin berkembang.

c. Mahasiswa dengan kemampuan awal rendah diharapkan agar lebih percaya diri dalam mengajukan masalah persamaan diferensial maupun masalah matematika lainnya sehingga kemampuannya dalam mengajukan masalah lebih baik dan kemampuan berpikir kreatifnya juga dapat berkembang.

2. Bagi Dosen

Dosen diharapkan dapat mengembangkan

model/pendekatanserta perangkat pembelajaran agar pembelajaran persamaan diferensial maupun pembelajaran matematika lainnya tidak monoton dan dapat merangsang serta melatihkan ke-mampuan berpikir kreatif mahasiswa sebagai calon guru matematika.

\section{DAFTAR PUSTAKA}

Arifin, Zainal. 2012. Penelitian Pendidikan: Metode dan Paradigma Baru. Bandung: PT. Remaja Rosdakarya.

Arikunto, Suharsimi. 2010. Prosedur Penelitian: Suatu Pendekatan Praktik. Jakarta: Rineka Cipta.

Depdiknas, 2006. Kurikulum Tingkat Satuan Pendidikan(KTSP). Jakarta: Departemen Pendidikan Nasional. 
Moleong, Lexy. 2012. Metodologi Penelitian Kualitatif Edisi Revisi. Bandung: PT Remaja Rosdakarya.

Sanders, Sarah. 2016. Critical and Creative Thinkers in Mathematics Classrooms. Journal of Student Engagement: Education Matters. Volume 6, Issue 1. The University of Wollongong Australia.

Siswono, T. Y. E.2005. Menilai Kreativitas Siswa dalam Matematika. Makalah disajikan dalam Prosiding Seminar Nasional Matematika dan Pendidikan
Matematika "Peranan Matematika dan terapannya dalam meningkatkan Sumber Daya Manusia Indonesia" di Jurusan FPMIPA Unesa, 28 Pebruari 2005, (Online), (https://tatagyes.files. wordpress.com/2009/11/paper05_nil aikreatif.pdf, Diunduh 16 Juni 2016).

Sugiyono. 2014. Metode Penelitian Kuantitatif, Kualitatif dan $R \& D$. Bandung: Alfabeta.

Suharsaputra, Uhar. 2012. Metode Penelitian Kuantitatif, Kualitatif, dan Tindakan. Bandung: Refika Aditama. 